\title{
Design of an Automatic Water Pump on a Traditional Boat
}

\author{
Ihsan $^{1)^{*}}$, Dirja Nur Ilham ${ }^{2)}$, Rudi Arif Candra ${ }^{3)}$, Amsar Yunan $^{4)}$, Hardisal ${ }^{5)}$ \\ 122)344)5) Politeknik Aceh Selatan, Indonesia \\ 1)ihsan@poltas.ac.id, ${ }^{2)}$ dirja@poltas.ac.id, ${ }^{3)}$ rudi_candra@poltas.ac.id, ${ }^{4)}$ amsar@poltas.ac.id, ${ }^{5)}$ \\ hardisal@poltas.ac.id
}

Submitted : Sep 16, $2020 \mid$ Accepted : Oct 8, $2020 \mid$ Published : Oct 8, 2020

\begin{abstract}
The process of draining traditional boat water efficiently is sometimes considered not very important for most fishermen. Because it is considered normal without realizing it can be detrimental, both in terms of time and work. One of the things that often makes the use of drained water less efficient is that draining the water from the boat is still done manually with human intervention. So that fishermen are engrossed in removing the puddle of boats and hindering their work. Based on the above problems, this study aims to make a traditional boat water channel control system automatically. This tool functions to control the volume of water in the boat and turn on and off the water pump engine automatically. This tool is able to remove standing water that enters the fishing boat automatically. The working principle of this tool, if the sensor detects water within $<=5 \mathrm{~cm}$, the water pump will turn on to remove / drain the water from the boat and the buzzer will light up as a signal that the puddle has reached an unsafe limit and if the water does not hit the sensor then the pump and buzzer will shut down automatically. The results of testing on the application of the tool made the accuracy obtained from 20 times the test obtained $85 \%$ of the results of successful sensor testing.
\end{abstract}

Keywords: Arduino uno, Water pump, Water sensor, Relay, Buzzer.

\section{INTRODUCTION}

As the largest archipelago country in the world, Indonesia has 17,499 islands from Sabang to Merauke. The total area of Indonesia is 7.81 million $\mathrm{km} 2$ consisting of 2.01 million $\mathrm{km} 2$ of land, 3.25 million $\mathrm{km} 2$ of sea, and 2.55 million km2 of the Exclusive Economic Zone (ZEE). (Mario Orlando, Desta Yolanda, \& Werman Kasoep, 2020). (Kamal, 2018).It is a country with an area of water larger than the land area so that some people work as fishermen. Thus boats are sea vehicles that are very often used by fishermen. sea in Indonesia.

The livelihoods of people who are dominant around the shoreline are people who work as fishermen. The material or materials used for making boats still use wood as the main material, the connection problem is the lack of density which will form a cavity and if the boat is used at sea, the cavity will be entered by water, so that leaks at the bottom of the boat are still frequent. occurs when fishermen go out to sea. Water that enters the boat must of course be disposed of immediately. If there is too much standing water in the boat, it will cause the boat to sink if it is not resolved quickly.

Disposing of water in boats, fishermen are currently still doing it manually by drawing water and then throwing it into the sea. This of course will be a problem for fishermen in doing their work and it takes a very long time. The above problems are complaints of fishermen when pulling water that enters the boat and slowing down work because the tools used are still manual. How to design an automatic water purifier on a traditional boat using the Arduino Uno.

There have been several previous studies that have been carried out related to this research "prototype water leak detection and automatic drainage systems on Arduino Uno and Labview based vessels" (Puthut Kurniawan, Rozeff Pramana, 2017)In this study, a prototype system for water leak detection and drainage was designed using a water level sensor as a water detection device and a submersible pump as a water dewatering device, and the Labview application as a monitoring system.

Furthermore, the research with the title "the design of an automatic water pump on an Arduino Uno-based fishing boat for a case study on the island of Terong, sub-district behind Padang, Batam City" (Sahidul Lukman, Rozeff Pramana, ST., 2017)This tool performs the process of removing water on the boat using an ultrasonic sensor, and can last for 2.4 hours and can pump water in a boat of 37 liters / minute.

Furthermore, there are also several studies that use technology using control using Arduino such as monitoring and stimulating heart rate (Ilham, Hardisal, Balkhaya, Candra, \& Sipahutar, 2019). Control lights with 
social media notifications (Candra, Ilham, Hardisal, \& Sriwahyuni, 2019). Automatic paddy gate controller (Dharma, Tansa, \& Nasibu, 2019). Automatic water machine control by utilizing Arduino with a smartphone (Lubis et al., 2019). Utilization of Arduino technology for automatic clothesline control (Murakabiman, Wahyu, \& Pratama, 2019). Home security uses arduino based on the internet of things (Rozi, Amnur, Fitriani, \& Primawati, 2018). Designing an Automatic Water Pump on an Arduino Uno Based Pancung Boat (Sahidul Lukman, Rozeff Pramana, ST., 2017). Early Warning Flood Detection Prototype Design Using Arduino and PHP (Wahyu Indianto, Awang Harsa Kridalaksana, 2017). And research on calculating energy efficiency with social media notifications (Candra \& Ilham, 2019).Automatic Fish Hatchery Pond Water Draining And Filling System Design Using Arduino With Water Turbidity Sensor(Daulay, 2018). Design of Automatic Aquarium Water Replacement Tool Based on Atmega8 Microcontroller(Ramadona, Haryanto, \& Tanjung, 2015). Design of Water Circulation System in Aquarium / Freshwater Fish Tub Based on Automatic Water Turbidity(Wadu, 2017).

From some of the studies above, this research will make automatic control of water drainage on traditional boats.

\section{LITERATURE REVIEW}

Traditional boats are water vessels, usually smaller than ocean liners. Some boats are usually carried by ship. However, the word boat actually experienced a narrowing in meaning, because at least until the 17th century, the boat referred to a large ship (see K'u-lun boat), even the Western galleon was once categorized as a boat, until it was replaced by the word "ship" in Indonesian and modern Malay. Wood is one of the basic ingredients that is often used daily, one of which is in the process of making traditional boats. The rampant deforestation causes scarcity and an increase in the price of basic wood which has an impact on increasing production costs. One of the efforts that can be made in the process of making traditional boats.

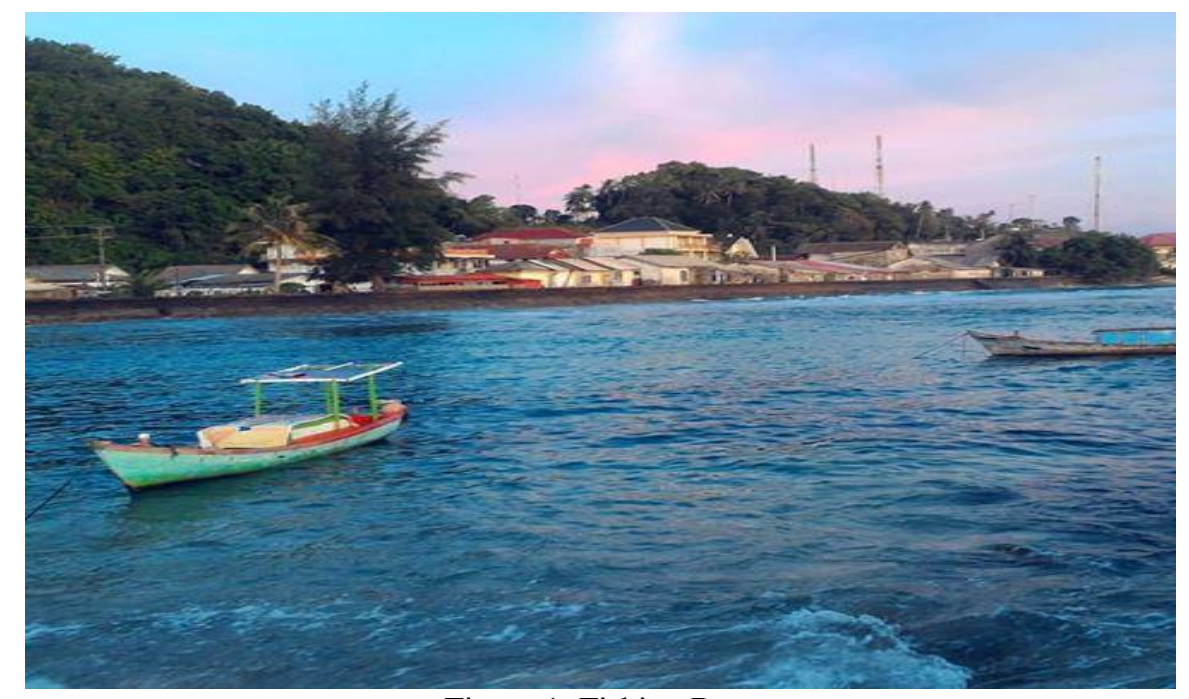

Figure 1. Fishing Boat

\section{METHOD}

The tools and materials used in the design of an automatic water drain on traditional boats include:

a. Hardware

Equipment requirements used in the design of the input warning device include:

Table 1

Hardware Specifications

\begin{tabular}{cll}
\hline No & \multicolumn{1}{c}{ Name } & \multicolumn{1}{c}{ Function } \\
\hline 1 & Arduino Uno R3 & Controller in the design of the infusion warning device \\
2 & Boat & As a place to test the tools made \\
3 & Water Pump & Serves as a water drain to be thrown out \\
4 & Water Sensor & Detect water entering the boat \\
5 & Buzzer & $\begin{array}{l}\text { Buzzer circuit or what is often called a series of alarm } \\
\text { message reminders and alerts }\end{array}$ \\
6 & Jumper & Connect the whole tool. \\
7 & Battery & As energy from the tools used \\
\hline
\end{tabular}

b. Software 
The software used in designing an automatic water purifier is:

Table 2

Software Requirements

\begin{tabular}{cll}
\hline No & \multicolumn{1}{c}{ Name } & \multicolumn{1}{c}{ Function } \\
\hline 1 & Arduino IDE & $\begin{array}{l}\text { Used to upload a low infusion warning program to the } \\
\text { Arduino board. }\end{array}$ \\
2 & Proteus & Used to simulate circuits \\
3 & Fritzing & Used to design circuit schematics and electronics \\
4 & Microsoft Visio & Used for designing drawings, schematics \\
\hline
\end{tabular}

\section{System planning}

2.

This design is made to simplify the process of designing an automatic water drain device as shown in Figure

(a)

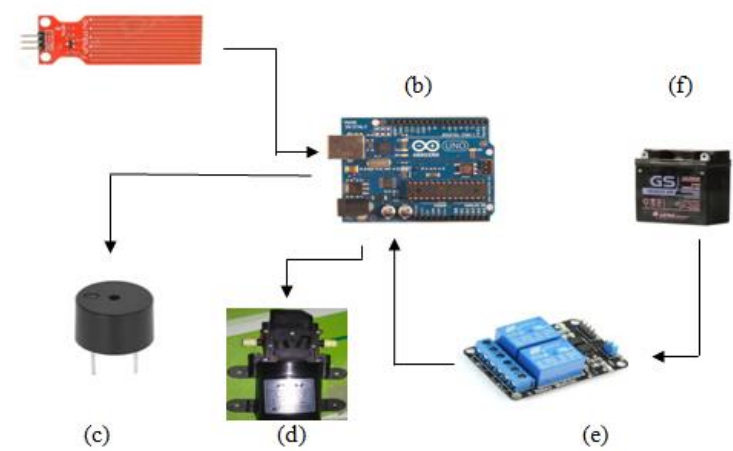

Figure 2. System Hardware Installation

Information :
a) Water Sensor
b) Arduino Uno
c) Buzzer
d) DC Water Pump
e) Relay
f) Battery

1. Working Principles of Tools

The following is a design for how an automatic water drain device works on a traditional boat using a water sensor shown in Figure 3

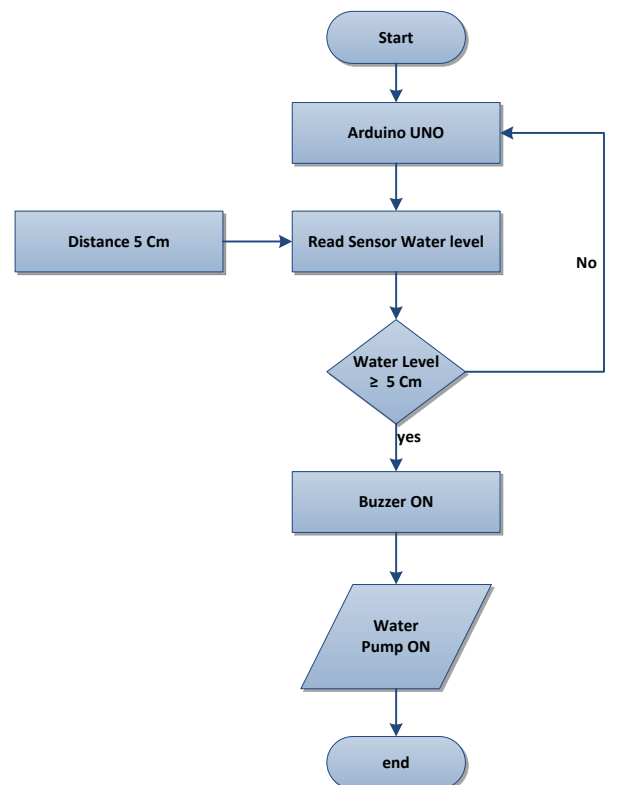

Figure 3. The working principle of the tool 
When the tool is turned on and Arduino begins to detect the distance of the water using a water sensor with a calculation if the distance of the sensor to the water is less or equal to five then the buzzer and water pump will turn on to drain the water in the traditional boat, otherwise if it is greater than five then the buzzer and the water pump will shut down.

\section{Schematic of Boat Drainage Equipment}

The boat is 4 meters long, 1 meter wide and 50 centimeters high, provided that the water limit to the sensor is 5 centimeters.

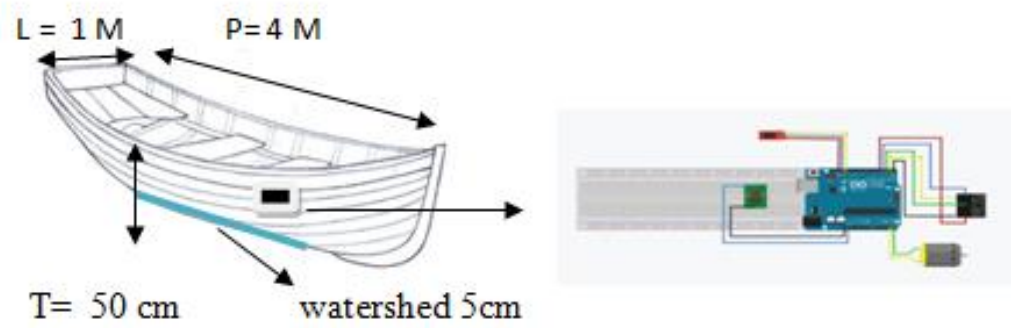

Figure 4. Schematic of the Tool

2. Sketch of Traditional Automatic Boat Drain Design

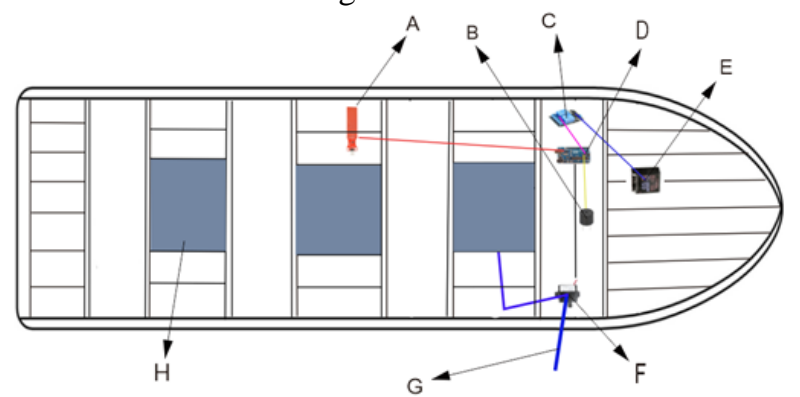

Information:

Figure 5.Sketch of Traditional Automatic Boat Drain Design
A. Water Sensor
B. Buzzer
C. Relay
D. Arduino Uno
E. Battery
F. Water Pump
G. Water Pipe
H. Water Entering the Boat

\section{RESULT}

The traditional boat water drains automatically based on the input from the water sensor, where the input from the water sensor will be the input for Arduino as the main controller to give orders to the pump so that the pump will work if the sensor hits water $\geq 5 \mathrm{~cm}$ then the pump will turn on and the buzzer will sound, if the sensor does not hit the water, the buzzer and pump will automatically shut down.

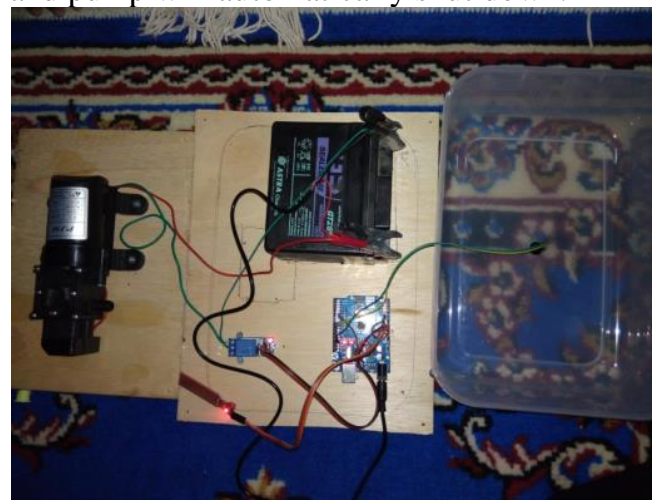

Figure 6. Whole tool suite 


\section{Testing Procedure}

In order for us to produce a design for the tool to work in accordance with the desired expectations based on the program that has been made, the tool testing is carried out. Tool testing is carried out in stages starting from testing the water sensor to testing the pump and testing the whole tool.

\section{Water Sensor Testing}

Sensor testing is carried out to find out that the sensor is working properly, water sensor testing is carried out with analog data $(5 \mathrm{~cm})$. the test steps are as follows:

1. Connect the battery and sensor to the Arduino board.

2. Connect the Arduino board with the computer via USB cable.

3. Make a sketch program and upload it to the Arduino board.

\section{Water Pump Testing}

Pump testing is done to find out that the pump used in the tool is working properly. The pump is connected to the COM pin on the relay in the connection to the pump, which means that the pump works if it gets logic 1 (high) or logic 0 (low) to run the pump, everything is set in the Arduino IDE program that is entered on the Arduino board. The test steps are as follows:

1. Connect the battery and pump to the Arduino board.

2. Connect the Arduino board with the computer via USB cable.

3. Create a sketch program by uploading it to the Arduino board.

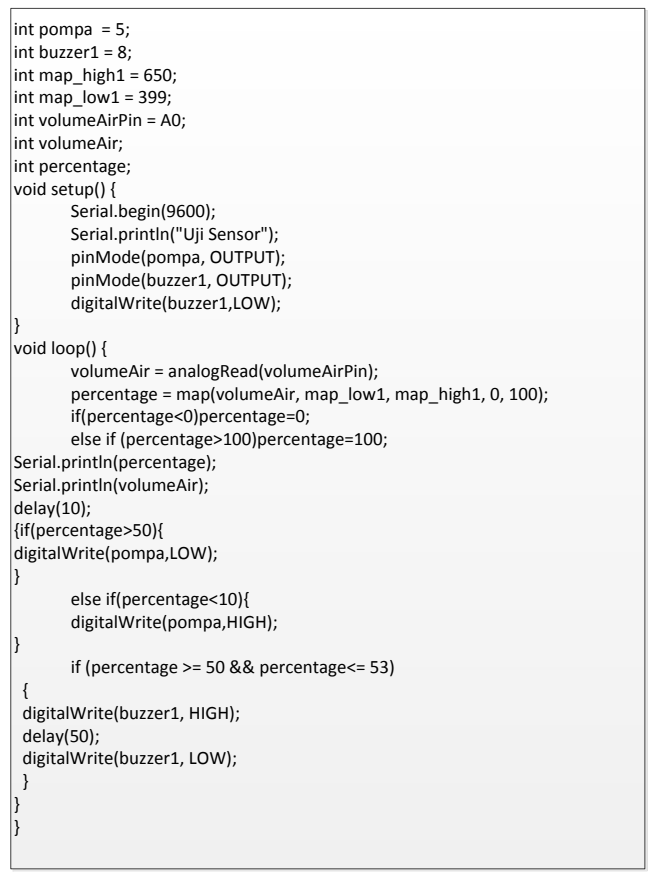

Figure 7. Sketch Program Arduino

Table 3

Water Pump Testing

\begin{tabular}{cccc}
\hline No & Testing & Time & $\begin{array}{c}\text { Amount of } \\
\text { Water }\end{array}$ \\
\hline 1 & Testing 1 & 1 minute & 1.5 Liter \\
2 & Testing 2 & 1 minute & 1.5 Liter \\
3 & Testing 3 & 1 minute & 1.5 Liter \\
4 & Testing 4 & 1 minute & 1.5 Liter \\
5 & Testing 5 & 1 minute & 1.5 Liter \\
6 & Testing 6 & 1 minute & 1.5 Liter \\
7 & Testing 7 & 1 minute & 1.5 Liter \\
\hline
\end{tabular}

Battery Life Testing 
Battery testing is carried out to determine the durability of the battery used in the tool that is working properly. The battery is connected to pin NO on the relay and connected to Arduino, which means that the battery will function when the pump is on. The battery can last \pm 5:49:30 hours. The test steps are as follows:

1. Connect the battery and pump to the Arduino board.

2. Connect the Arduino board with the computer via USB cable.

3. Create a sketch program by uploading it to the Arduino board.

\section{Overall Tool Testing}

To operate a traditional boat water dewatering device automatically using a water sensor is as follows:

1. first assemble all the tools into one unit and ready to operate.

2. After all the tools are connected, connect the cable to the battery which is the main voltage source. After connecting to the battery, the whole circuit will be active, and the sensor will work according to system work, if the sensor detects water within $\leq 5 \mathrm{~cm}$, the bell and pump will start automatically and if the sensor distance does not hit the water, the bell and the pump will automatically shut down .

Table 4

Overall Tool Test Results

\begin{tabular}{|c|c|c|c|c|}
\hline No & Testing & $\begin{array}{l}\text { Depth of the } \\
\text { assessor in } \\
\text { the water }\end{array}$ & $\begin{array}{c}\text { Buzzer and } \\
\text { Pump } \\
\text { conditions }\end{array}$ & Information \\
\hline 1 & Testing 1 & $5 \mathrm{~cm}$ & on & corresponding \\
\hline 2 & Testing 2 & $3 \mathrm{~cm}$ & off & It is not in accordance with \\
\hline 3 & Testing 3 & $1 \mathrm{~cm}$ & off & corresponding \\
\hline 4 & Testing 4 & $7 \mathrm{~cm}$ & on & corresponding \\
\hline 5 & Testing 5 & $5 \mathrm{~cm}$ & on & corresponding \\
\hline 6 & Testing 6 & $3 \mathrm{~cm}$ & off & corresponding \\
\hline 7 & Testing 7 & $6 \mathrm{~cm}$ & on & corresponding \\
\hline 8 & Testing 8 & $5 \mathrm{~cm}$ & on & corresponding \\
\hline 9 & Testing 9 & $8 \mathrm{~cm}$ & on & corresponding \\
\hline 10 & Testing 10 & $6 \mathrm{~cm}$ & off & It is not in accordance with \\
\hline 11 & Testing 11 & $5 \mathrm{~cm}$ & on & corresponding \\
\hline 12 & Testing 12 & $2 \mathrm{~cm}$ & off & corresponding \\
\hline 13 & Testing 13 & $5 \mathrm{~cm}$ & on & corresponding \\
\hline 14 & Testing 14 & $5 \mathrm{~cm}$ & on & corresponding \\
\hline 15 & Testing 15 & $5 \mathrm{~cm}$ & on & corresponding \\
\hline 16 & Testing 16 & $5 \mathrm{~cm}$ & on & corresponding \\
\hline 17 & Testing 17 & $5 \mathrm{~cm}$ & off & It is not in accordance with \\
\hline 18 & Testing 18 & $6 \mathrm{~cm}$ & on & corresponding \\
\hline 19 & Testing 19 & $6 \mathrm{~cm}$ & on & corresponding \\
\hline 20 & Testing 20 & $5 \mathrm{~cm}$ & on & corresponding \\
\hline
\end{tabular}

\section{DISCUSSIONS}

From the results described above, it is clear that the application of the tools made is very useful, namely to maximize the time for fishermen to catch fish without having to think about draining the water in the boat, so that it is hoped that fishermen can focus more on catching the fish they catch. Judging from the research conducted by previous research, this tool is more focused on being applied to small, simple fishing boats so that if applied to larger fishing boats or boats, it is necessary to recalculate the capacity and time required to use this tool.

\section{CONCLUSION}

Based on the results of testing automatic water drainage devices on traditional boats, several conclusions can be drawn:

From the results of battery life testing, the battery can last \pm 05:49:30 hours to drain the water in the boat.From the results of tests that have been carried out as many as 7 times, there is an average result of the pump's ability to drain water in the boat reaching $1.5 \mathrm{~L} /$ minute.From the test results that have been carried out as much as 20 times, the results of the suitability of the water pump conditions are $85 \%$. 


\section{REFERENCES}

Candra, R. A., \& Ilham, D. N. (2019). Analisis Efisiensi Energi pada Aplikasi Media Sosial Menggunakan Perangkat Komunikasi Bergerak. 9, 125-131.

Candra, R. A., Ilham, D. N., Hardisal, H., \& Sriwahyuni, S. (2019). Light Control Design by Using Social Media Telegram Applications Based on Internet Of Things (IOT). SinkrOn, 3(2), 200. https://doi.org/10.33395/sinkron.v3i2.10094

Daulay, N. K. (2018). Desain Sistem Pengurasan Dan Pengisian Air Kolam Pembenihan Ikan Secara Otomatis Menggunakan Arduino Dengan Sensor Kekeruhan Air. VI(1), 58-63.

Dharma, I. P. L., Tansa, S., \& Nasibu, I. Z. (2019). Perancangan Alat Pengendali Pintu Air Sawah Otomatis dengan SIM8001 Berbasis Mikrokontroler Arduino Uno. Jurnal Teknik, 17(1), 40-56. https://doi.org/10.37031/jt.v17i1.25

Ilham, D. N., Hardisal, H., Balkhaya, B., Candra, R. A., \& Sipahutar, E. (2019). Heart Rate Monitoring and Stimulation with the Internet of Thing-Based (IoT) Alquran Recitation. SinkrOn, 4(1), 221. https://doi.org/10.33395/sinkron.v4i1.10392

Kamal, M. M. (2018). Penegakan Hukum Pencurian Ikan di Wilayah Zona Ekonomi Eksklusif Indonesia (ZEEI). Jurist-Diction, 1(2), 609-626.

Lubis, Z., Lungguk, A., Saputra, N., Winata, S., Annisa, A., Muhazzir, B., ... Sri, W. (2019). Kontrol Mesin Air Otomatis Berbasis Arduino Dengan Smartphone. Cetak) Buletin Utama Teknik, 14(3), 1410-4520.

Mario Orlando, Desta Yolanda, \& Werman Kasoep. (2020). Sistem Monitoring dan Penjernihan Air Berdasarkan Derajat Keasaman $(\mathrm{PH})$ dan Kekeruhan Pada Bak Penampungan Air Berbasis Internet of Things. Chipset, 1(01), 17-22. https://doi.org/10.25077/chipset.1.01.17-22.2020

Murakabiman, Z., Wahyu, M., \& Pratama, C. (2019). Pemanfaatan Arduino Uno Untuk Jemuran Pakaian Otomatis. (May), 0-10. https://doi.org/10.13140/RG.2.2.33146.34246

Puthut Kurniawan, Rozeff Pramana, D. N. (2017). Prototipe Sistem Deteksi Kebocoran Air dan Pengurasan secara Otomatis pada Kapal Berbasis Arduino Uno dan LabView. (9), 21-22.

Ramadona, A. S., Haryanto, E. V., \& Tanjung, M. R. (2015). Perancangan Alat Pengganti Air Aquarium Otomatis Berbasis Mikrokontroler Atmega8. CSRID (Computer Science Research and Its Development Journal), 6(1), 1. https://doi.org/10.22303/csrid.6.1.2014.1-10

Rozi, F., Amnur, H., Fitriani, F., \& Primawati, P. (2018). Home Security Menggunakan Arduino Berbasis Internet Of Things. INVOTEK: Jurnal Inovasi Vokasional Dan Teknologi, 18(2), 17-24. https://doi.org/10.24036/invotek.v18i2.287

Sahidul Lukman, Rozeff Pramana, ST., M. (2017). Perancangan Pompa Air Otomatis pada Boat Pancung Berbasis Arduino Uno untuk Studi Kasus di Pulau Terong Kecamatan Belakang Padang Kota Batam.

Wadu, R. A. (2017). Rancang Bangun Sistem Sirkulasi Air Pada Akuarium/ Bak Ikan Air Tawar Berdasarkan Kekeruhan Air Secara Otomatis. Jurnal Ilmiah FLASH, 3(November), 1-10.

Wahyu Indianto, Awang Harsa Kridalaksana, Y. (2017). Perancangan Sistem Prototipe Pendeteksi Banjir Peringatan Dini Menggunakan Arduino dan PHP. 12(1). 